\title{
CONCURRENT ENGINEERING MODEL (CEM) ANALYSIS ON LOGISTICS DESIGN PARAMETERS - A CASE STUDY
}

\author{
J.S. Gnanasekaran ${ }^{1}$ and S. Shanmugasundaram ${ }^{2}$ \\ ${ }^{1}$ Department of Mechanical Engineering \\ Sri Krishna College of Engineering and Technology, India \\ jsgsekar@yahoo.com \\ ${ }^{2}$ Department of Mechanical Engineering \\ Government College of Technology, India \\ sssundaramgct@yahoo.com
}

\begin{abstract}
Logistics engineering can be divided into internal or in-plant logistics and external manufacturing logistics. Internal (in-plant) logistics include material handling, warehousing, and storage systems, while external manufacturing logistics include transportation. Both must be integrated to minimise costs at a competitive level of service. For example, plant layout and production planning must consider internal logistics. The design decisions are made in the early phases of product design, and development will have a significant effect over future manufacturing and logistical activities. In this paper, a methodology is developed and presented to minimise the design cycle time of any manufacturing firm, including their suppliers, and to maximise the whole system's effectiveness.
\end{abstract}

\section{OPSOMMING}

Logistieke ingenieurswese kan verdeel word in interne of binne-aanleg logistiek en eksterne vervaardigingslogistiek. Interne (binne-aanleg) logistiek behels materiaalhantering, berging en voorraadhoudingsisteme, terwyl eksterne vervaardigingslogistiek vervoer insluit. Die fasette moet geintegreer wees om koste te minimiseer by ' $n$ mededingende diensvlak. So byvoorbeeld moet die uitleg van ' $n$ aanleg en produksiebeplanning interne logistiek in aanmerking neem. Die ontwerpbesluite word geneem in die beginstadium van die produkontwerp en ontwikkeling sal ' $n$ betekenisvolle invloed hê op toekomstige vervaardigings- en logistieke aktiwiteite. In hierdie artikel word ' $n$ metodologie ontwikkel en aangebied om die ontwerpsiklustyd van enige vervaardigingsonderneming te minimiseer met inagneming van die leweransiers om sodoende die totale sisteem se effektiwiteit te maksimiseer. 


\section{INTRODUCTION}

Many people think that logistics means only warehouses and trucks. However, genuine logistics is concerned with all the activities of an enterprise that ensure that customers are given total satisfaction at the lowest cost. This means that almost every function of an organisation is involved in the logistics process. In complex manufacturing processes with many different product lines, it is not possible to respond fast enough to match the customer's exact demands every day. That is why firms need to keep finished goods in stock (Ballou [1]).

However, it is possible to improve responsiveness, and so reduce the extent of stock, by careful control of shop floor processes Christopher [5]. This might mean working to reduce batch sizes and speed up changeovers, or it might mean improving forecasting methods so that output can be adjusted in advance of a rise or fall in demand (Blanchard [2], Blanchard \& Fabrycky [4]). Most manufacturing organisations are making their products without considering the logistics parameters. In our study, we observed that the logistics features are available to them, directly or indirectly, in their manufacturing activities. However, larger manufacturing firms have separate departments for logistics, while smaller manufacturing firms give little importance to logistics. This paper supports a trade-off between smaller and larger firms for the easy implementation of logistical design.

\section{OBJECTIVES AND ORGANISATION OF THE PAPER}

The objective of this paper is threefold.

- To demonstrate the importance of early logistics involvement in the product design and development process.

- $\quad$ To present a conceptual as well as an analytical basis for integrating logistics concerns, constraints, and contributions in the design process.

- $\quad$ To provide a product design conceptual framework, where the managerial implications of design for logistics can be explored.

The efficiency and effectiveness of the methodology, results, and their managerial implications are analysed. Section 3 briefly covers theoretical issues of interest when discussing product design in the concurrent engineering environment, and presents a logistics design framework model for integrated product design. Section 4 comprises the application of cluster algorithms, and presents a concurrent engineering model (CEM) that was adopted in a case study, and its results. Finally, Section 5 discusses the theoretical/managerial implications of the process model, and makes recommendations for further research.

\section{PRODUCT DESIGN IN A CONCURRENT ENGINEERING ENVIRONMENT}

This paper focuses on an interdisciplinary approach that utilises methods, procedures, and rules to plan, analyse, select, and optimise the design of products. In the early stages of the design process, concurrent engineering considers and includes various product design attributes, such as aesthetics, durability, ergonomics, interchangeability, logistics, maintainability, marketability, manufacturability, procurability, reliability, remanufacturability, safety, schedulability, serviceability, simplicity, testability, and transportability (Prasad [3]). The greatest impact and benefits of concurrent engineering are realised at the design stage of product development. This paper supports the involvement of logistics in the early phases of product design and development in a concurrent engineering environment. This environment - and the benefits of such involvement - are considered in detail (Gnanasekaran [10], Kovaicheliyan [14], Zangwill [15]). The research facilitates the design interface between the designer and the logistician.

A quantitative and conceptual interface for logistics design is considered in the four interfaces - i.e., logistics engineering, manufacturing logistics, design for packaging, and 
design for transportability. Modularity, as a basic rule of good design, is more easily changed, expanded, or contracted than large and complex system designs. Most managers find modular system designs easier to understand and apply (Kusiak [7], Gnanasekaran [8], [9]). The module families can be designed according to the design for logistics and implemented simultaneously. This can potentially reduce the total design cycle time and bring the advantages of concurrent engineering to the design of integrated logistics. This paper has specifically explored a large number of areas where collaboration at the interface of logistics and design activities can result in significant achievements for a manufacturing enterprise.

\subsection{Logistic design framework model for integrated product design}

There are two issues at the core of the successful implementation of concurrent engineering:

[1] All activities related to the development of a product should be focused on the early stages of product design, so that the greatest benefits of such integration are achieved. The information requirements and exchanges at the conceptual design stage are not well defined and are usually fuzzy. This poses a challenge for implementing concurrent engineering.

[2] The impact and constraints associated with various functional requirements should be communicated to the designer accurately, relevantly, and in good time.

Figure 1 represents an integrated logistics system as it relates to product design. As shown, an effective design for logistics cuts across a number of functional areas. These activities converge on product design as the embodiment of all future activities. Just as the design for logistics affects other functional areas, so other areas affect logistics considerations. This process is an inherently dynamic one that requires negotiation and trade-off among the functional areas in a concurrent engineering environment. Different functional areas and their interrelationships should be explored, and may culminate in several other research articles. The focus of this paper, however, is on exploring and analysing the link between logistics and product design.

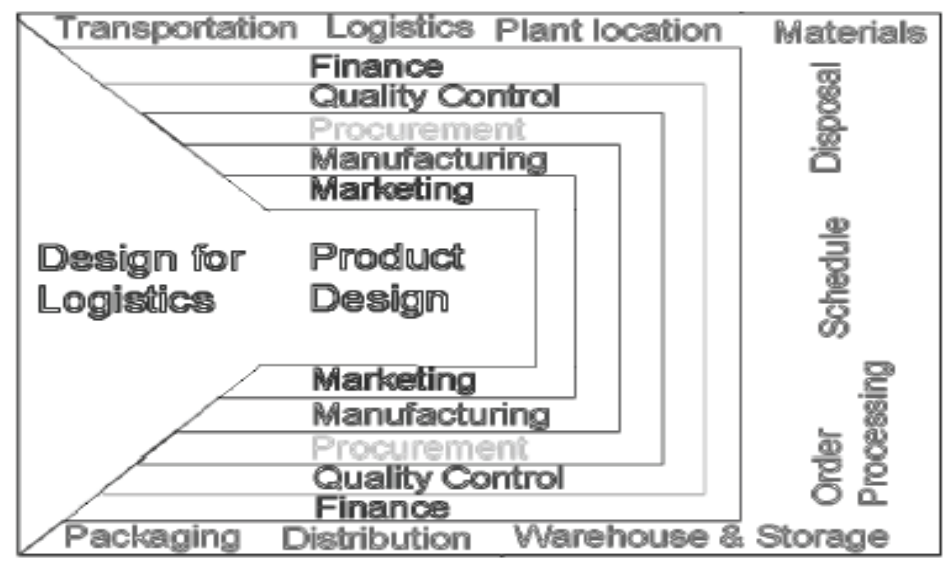

Figure 1: Integrated logistics system for product design

\subsection{Conceptual logistics framework for product design}

The system approach to design for logistics essentially includes the designer's functional requirements as well as the logistician's requirements of availability, supportability, cost, quality, volume changes, timely delivery, order frequencies, etc. The design for logistics can be decomposed into four subsystems: logistics engineering, manufacturing logistics, 
design for packing, and design for transportability. To achieve flexibility, design economics, and overall design optimisation, the design for logistics needs to be decomposed further into manageable and homogeneous units for processing the data.

\subsection{Logistic design parameters}

In addition to the above, the manageable and homogeneous units are called 'modules' here for the sake of simplicity. Therefore, each subsystem is divided into modules, of which there can be several. Modules are the building blocks of design for logistics. Each module is further decomposed into design parameters. Each module, then, has several design parameters that must be considered in the design of that particular module. Design parameters are the smallest functional requirements in the overall design of logistics. The detailed design parameters used in this paper were collected from various units of a manufacturing and service industry at on-site and off-site locations. About two hundred design parameters were collected and analysed. Various modules under the different subsystems of the design for logistics were also found. The collection of design parameters is important and appropriate to the product being manufactured in the organisation according to the design requirement, since it is based on the decisions of designers and logisticians.

\subsection{Clustering algorithms}

The 'decomposition' process is defined as a process that breaks down a task or problem into a set of independent entities. There are two classes of decomposition methods: formal and intuitive. Formal methods decompose a problem based on its mathematical representation. In intuitive methods, understanding the physics or functions of the system is the prime factor directing decomposition. The latter methods provide an alternative way of decomposing those problems that do not possess a structure, and are therefore not susceptible to formal decomposition methods. Decomposition has been applied in many areas, ranging from medicine and biology to computer science and manufacturing. In manufacturing, decomposition has been used under the term 'group technology'. Decomposition simplifies the design process, and allows one to determine a potential group of tasks that might be performed simultaneously. As a result of decomposition, the design and manufacturing cycle time can be reduced. Another advantage of applying decomposition in design is the simplification of scheduling and management of design and manufacturing projects (Kusiak [6]).

\subsection{Group technology in concurrent engineering}

Batch manufacturing is a dominant activity in the world, generating much industrial output. The major characteristics of batch manufacturing are a level of product variety and small manufacturing lot sizes. The product variations present design engineers with the problem of a design stage that significantly affects manufacturing cost, quality, and delivery times. The impacts of these product variations in manufacturing are high investment in equipment, high tooling costs, complex scheduling and loading, lengthy set-up times and high set-up costs, excessive scrap, and high quality control costs. However, to compete in a global market, it is essential to improve productivity in small batch manufacturing industries.

\section{CONCURRENT ENGINEERING MODEL (CEM) ANALYSIS}

In this paper, the complexity of design problems was decomposed into simplified sub-design problems by using a new concept: CEM analysis. This can be measured, using an optimising procedure to maximise some measure of effectiveness (MOE).

The forming of these cluster families allows a designer concurrently to consider and design the design parameters common to a set of modules. This modularised approach increases the efficiency of logistics design. The interactions between modules and design parameters 
can be represented in a binary module design parameter incidence matrix. The CEM analysis is integrated with an optimisation approach to minimise the design cycle time. The CEM model designed for this research is shown in Figure 2.

\begin{tabular}{|l|l|}
\hline \multicolumn{2}{|c|}{ CONCURRENT ENGINEERING MODEL (CEM) } \\
\hline Maximise & System effectiveness \\
\hline Minimise & Design cycle time \\
\hline Subject to logistics integrated & Logistics engineering \\
\cline { 2 - 2 } $\begin{array}{l}\text { product design sub-systems (and } \\
\text { modules with design } \\
\text { parameters) such as: }\end{array}$ & Manufacturing logistics \\
\cline { 2 - 2 } & Design for packaging \\
\cline { 2 - 2 } & Design for transportability \\
\hline
\end{tabular}

Figure 2: Concurrent engineering model (CEM)

The objective of this research is to develop a simultaneous optimisation model of a product design system, to minimise the design cycle time and maximise the system effectiveness with respect to all decision variables. The model evaluates alternative design solutions by calculating the associated operational effectiveness as well as manufacturing and logistics support systems. The objective function contains two components that are conflicting in nature. Manufacturing organisations are interested in minimising design cycle time, and in maximising system effectiveness. The multi-criteria nature of this optimisation is unavoidable. In order to model it, we combine these two criteria into a single objective function, i.e. DCT+ MR (SI), where $(\mathrm{SI})$ is system ineffectiveness and MR is the marginal rate of substitution between DCT and (SI).

In determining an appropriate value for MR, the designers have to specify the trade-off between DCT and (SI) based on the relative worth of each measure - that is, maximise system effectiveness subject to a constraint on DCT, or minimise DCT subject to a constraint on system effectiveness. The objective function, DCT+MR (SI), can be separated into individual constituent functions that are combined in stages. So it is necessary to develop an optimisation procedure by considering the value and behaviour of these systems and their dependencies on decision variables, in order to break down this large optimisation problem into manageable sub-problems.

\subsection{Development of an optimisation procedure}

The optimisation procedure best suited for this research utilises a concurrent engineering model (CEM) analysis called the bond energy algorithm (BEA), which is a clustering approach to the design for logistics systems. This algorithm maximises some measure of effectiveness (MOE) for the defined system. Conversely, if the measurement of effectiveness is maximised in a system, then conceptually, the outcome of the system reduces the design cycle time considerably. Thus no separate optimisations are required for optimising DCT. The existing BEA is modified according to the CEM analysis to enrich cluster density and enhance cluster efficiency.

\subsection{Methodology}

This paper is based on both desk research and field research, providing a logistics support perspective on the product design process. This desk research has been further developed in co-operation with the field studies through day-to-day work in a manufacturing firm and its suppliers. The objective is to maximise system effectiveness and minimise design cycle time.

The existing cluster algorithm called bond energy algorithm (BEA) (McCormick [13]) was analysed for this study, and used to develop a model for enhancing cluster efficiency, and to introduce the same for computational purposes to get rich clusters for the appropriate family of logistics design. An incidence matrix was designed to represent the assignment of 
design parameters to modules. In the incidence matrix the $a_{i j}$ entries correspond to the available design parameters. Entering a ' 1 ' in the matrix signifies that the inclusion of a particular design parameter in a module is a necessary and essential requirement of forming that module; otherwise a ' 0 ' is entered. Each module inherently consists of a set of cohesive and bounded design parameters whose interactions determine the overall design and effectiveness of the module. The design parameters may vary from one design to another, depending on the unique requirements of each logistics system design.

A study was conducted in a company in the automotive industry, and tested the logistics design parameters with respect to available subsystems with different modules. The methodology used in this paper generates modules that are cohesive, bounded, or contain a self-contained group of activities. For effective implementation of integrated logistics design, each module solves one clearly-defined segment of the total system. These clustering algorithms are used for the decomposition of complex design problems into simple and manageable sub-design problems. A case study for this problem is presented below to test and validate the algorithm.

\subsection{Case Study}

The study was mainly focused on logistics concerns and supplier activities in the relationship between a main industry and a chain connecting it to many suppliers. The manufacturer follows regular manufacturing practices, including product design and development, tool design, die design, raw material planning, scheduling, inventory, manufacturing, storage and warehousing, etc. The problem is to make a link between the main industry and the disposal of products to the customer, and to segregate the various logistics and logistics design activities involved in manufacturing activities from product design and development. From the above system, every supplier also has some subsuppliers of various secondary operations of manufacturing components. The study took all the necessary steps to link all the activities between the manufacturers and the suppliers. It produced high bond energy clusters by the incremental rise in system effectiveness when comparing the existing design, and proposed the module-based logistics design. The data collected for this case study are shown in Table 1 . The resulting clusters are shown in Figure 3.

The modular-based design approach constructed for this study relates to logistics and product design. The major steps in system design and development, and the interface relationships between the basic design and logistics functions, are included in this study. The principle of concurrent engineering is accomplished through the intensive teamwork between product design and development, production planning, and manufacturing. 


\begin{tabular}{|c|c|c|c|c|}
\hline $\begin{array}{l}\text { Row } \\
\text { nr }\end{array}$ & $\begin{array}{l}\text { Module } \\
\text { (M) }\end{array}$ & $\begin{array}{l}\text { Design parameters } \\
\text { (DP) }\end{array}$ & Notation & Col nr \\
\hline 1 & $\begin{array}{l}\text { Design for } \\
\text { Supportability } \\
\text { (M1) }\end{array}$ & $\begin{array}{l}\text { Supportability analysis (including } \\
\text { suppliers) } \\
\text { Product performance Carrier type }\end{array}$ & $\begin{array}{l}(M 1.1) \\
(M 1.2) \\
(M 1.3)\end{array}$ & $\begin{array}{l}2 \\
3\end{array}$ \\
\hline 2 & $\begin{array}{l}\text { Design for } \\
\text { Manufacturability } \\
\text { (M2) }\end{array}$ & $\begin{array}{l}\text { Die tool design for die casting } \\
\text { Die manufacturing and sample } \\
\text { submission } \\
\text { Sample validation }\end{array}$ & $\begin{array}{l}(M 2.1) \\
(M 2.2) \\
(M 2.3)\end{array}$ & $\begin{array}{l}4 \\
5\end{array}$ \\
\hline 3 & $\begin{array}{l}\text { Product lines } \\
\text { (M3) }\end{array}$ & $\begin{array}{l}\text { Die casting product line } \\
\text { Design lead times } \\
\text { Product seasonality }\end{array}$ & $\begin{array}{l}\text { (M3.1) } \\
\text { (M3.2) } \\
\text { (M3.3) }\end{array}$ & $\begin{array}{l}7 \\
8 \\
9\end{array}$ \\
\hline 4 & $\begin{array}{l}\text { Design attributes } \\
\text { (M4) }\end{array}$ & $\begin{array}{l}\text { Material mix ratio } \\
\text { Failure rate per unit time } \\
\text { Inspection (visual, sample, process } \\
\text { capability) }\end{array}$ & $\begin{array}{l}\text { (M4.1) } \\
(M 4.2) \\
(M 4.3)\end{array}$ & $\begin{array}{l}10 \\
11 \\
12\end{array}$ \\
\hline 5 & $\begin{array}{l}\text { Manufacturing } \\
\text { Processes } \\
\text { (M5) }\end{array}$ & $\begin{array}{l}\text { Aluminum die casting } \\
\text { Production volume } \\
\text { Secondary operations }\end{array}$ & $\begin{array}{l}\text { (M5.1) } \\
(M 5.2) \\
(M 5.3)\end{array}$ & $\begin{array}{l}13 \\
14 \\
15\end{array}$ \\
\hline 6 & $\begin{array}{l}\text { Production planning } \\
\text { and control } \\
\text { (M6) }\end{array}$ & $\begin{array}{l}\text { Machine set-up times Inventory } \\
\text { level Scheduling (including } \\
\text { suppliers) }\end{array}$ & $\begin{array}{l}(M 6.1) \\
(M 6.2) \\
(M 6.3)\end{array}$ & $\begin{array}{l}16 \\
17 \\
18\end{array}$ \\
\hline 7 & $\begin{array}{l}\text { Materials } \\
\text { (M7) }\end{array}$ & $\begin{array}{l}\text { ADC aluminium procurement } \\
\text { Material availability } \\
\text { Logistics of material move }\end{array}$ & $\begin{array}{l}\text { (M7.1) } \\
(M 7.2) \\
(M 7.3)\end{array}$ & $\begin{array}{l}19 \\
20 \\
21\end{array}$ \\
\hline 8 & $\begin{array}{l}\text { Plant location } \\
\text { (M8) }\end{array}$ & $\begin{array}{l}\text { Multiple warehouses } \\
\text { Demand schedule }\end{array}$ & $\begin{array}{l}\text { (M8.1) } \\
\text { (M8.2) }\end{array}$ & $\begin{array}{l}22 \\
23\end{array}$ \\
\hline 9 & $\begin{array}{l}\text { Packaging materials } \\
\text { (M9) }\end{array}$ & $\begin{array}{l}\text { Plastic partitioned Containers } \\
\text { Strength of material (package } \\
\text { material, tensioners, etc) }\end{array}$ & $\begin{array}{l}(M 9.1) \\
(M 9.2)\end{array}$ & $\begin{array}{l}24 \\
25\end{array}$ \\
\hline 10 & $\begin{array}{l}\text { Packaging and testing } \\
\text { (M10) }\end{array}$ & $\begin{array}{l}\text { Shock levels } \\
\text { Vibration }\end{array}$ & $\begin{array}{l}(\text { M10.1) } \\
(\text { M10.2) }\end{array}$ & $\begin{array}{l}26 \\
27\end{array}$ \\
\hline 11 & $\begin{array}{l}\text { Packaging design } \\
\text { features } \\
\text { (M11) }\end{array}$ & $\begin{array}{l}\text { Packaging shape, size and modules } \\
\text { Package ease of handling }\end{array}$ & $\begin{array}{l}(M 11.1) \\
(M 11.2)\end{array}$ & $\begin{array}{l}28 \\
29\end{array}$ \\
\hline 12 & $\begin{array}{l}\text { Functional packaging } \\
\text { requirements } \\
\text { (M12) }\end{array}$ & $\begin{array}{l}\text { Transportation requirements } \\
\text { Shipping and handling requirements }\end{array}$ & $\begin{array}{l}\text { (M12.1) } \\
\text { (M12.2) }\end{array}$ & $\begin{array}{l}30 \\
31\end{array}$ \\
\hline 13 & $\begin{array}{l}\text { Transportation mode } \\
\text { (M13) }\end{array}$ & $\begin{array}{l}\text { Product density } \\
\text { Number of carriers }\end{array}$ & $\begin{array}{l}(M 13.1) \\
(M 13.2)\end{array}$ & $\begin{array}{l}32 \\
33\end{array}$ \\
\hline 14 & $\begin{array}{l}\text { Transportability } \\
\text { design criteria } \\
\text { (M14) }\end{array}$ & $\begin{array}{l}\text { Average transit time } \\
\text { Product time to market }\end{array}$ & $\begin{array}{l}(M 14.1) \\
(M 14.2)\end{array}$ & $\begin{array}{l}34 \\
35\end{array}$ \\
\hline 15 & $\begin{array}{l}\text { Transportability } \\
\text { requirements } \\
\text { (M15) }\end{array}$ & $\begin{array}{l}\text { Transport method } \\
\text { Type of packaging }\end{array}$ & $\begin{array}{l}\text { (M15.1) } \\
\text { (M15.2) }\end{array}$ & $\begin{array}{l}36 \\
37\end{array}$ \\
\hline
\end{tabular}

Table 1: Data for case study 


\subsection{Results}

In Figure 3, it is apparent that each module family (MF) addresses its respective modules, and each design parameter family (DPF) addresses its respective design parameters. The detailed results are given below:

[1] Module Family 1 addresses supportability and transportability issues. It consists of design for supportability, transportation requirements, and transportability design criteria.

[2] Module Family 2 addresses material and manufacturability issues. It consists of design for manufacturability, manufacturing processes and materials, and materials.

[3] Module Family 3 concentrates on product lines and product planning issues. It consists of the product lines, production planning and control, and plant location.

[4] Module Family 4 focuses on design characteristics. It consists of design attributes, packaging and testing, and packaging design features.

[5] Module Family 5 concentrates on packaging criteria. It consists of functional packaging requirements, transportation mode, and packaging materials.

The initial measurement of system effectiveness (MSE) value obtained for this study was 35 , and the final MSE was 122, due to the above results. The system effectiveness is maximised, and hence the clustering process releases the highest bond energy, and the solution consists of optimal bond energy. The above result (shown in Figure 3 ) indicates that the overall design of logistics can be accomplished in five self-contained clusters or modules. Design Parameter Family 3 (DPF3) formed a checkerboard cluster, while the other families formed diagonal bodies. The objective of BEA in logistics design has been attained through clustering. The design for logistics model results in five module families with related design parameters. The application of a Gantt chart and of concurrent engineering principles by overlapping the module family resulted in a reduced design cycle time for this study of 1.5 weeks. The total cycle time for the existing system was 13.5 weeks.

\section{CONCLUSION}

In this research, a methodology is developed and presented for the decomposition of the design process. A concurrent engineering model (CEM) is developed and integrated with an enhanced bond energy algorithm (BEA) to analyse the modular design for logistics. This new approach releases the highest bond energy. A logistics engineering model called 'the Design for Logistics Model for Product Design Framework' was developed for this research. The application of CEM and its features in this research maximised the logistics system's effectiveness and minimised the design cycle time for the product design for logistics, subject to logistics subsystems, modules, and parameters.

The study has resulted in significant achievements for a manufacturing enterprise through manufacturing logistics (Gnanasekaran [11],[12]). Concurrent engineering and design for manufacturing provides a continuous development to consider the logistics problems. The contributions of logistics and its constraints are enriched in the early phases of product design cycle. The merits of concurrent engineering were realised under the logistics requirements as a part of the overall product design. A logistics engineering model called 'the Design for Logistics Model for Product Design Framework' was developed for this research. This model worked as a tool for the logistician to include the necessary and relevant subsystems, modules, and design parameters. This approach allows the designer to make a full contribution to logistics system design. This methodology is applicable to matrices of any size or shape. The only requirement is that the elements of a matrix should be positive. 


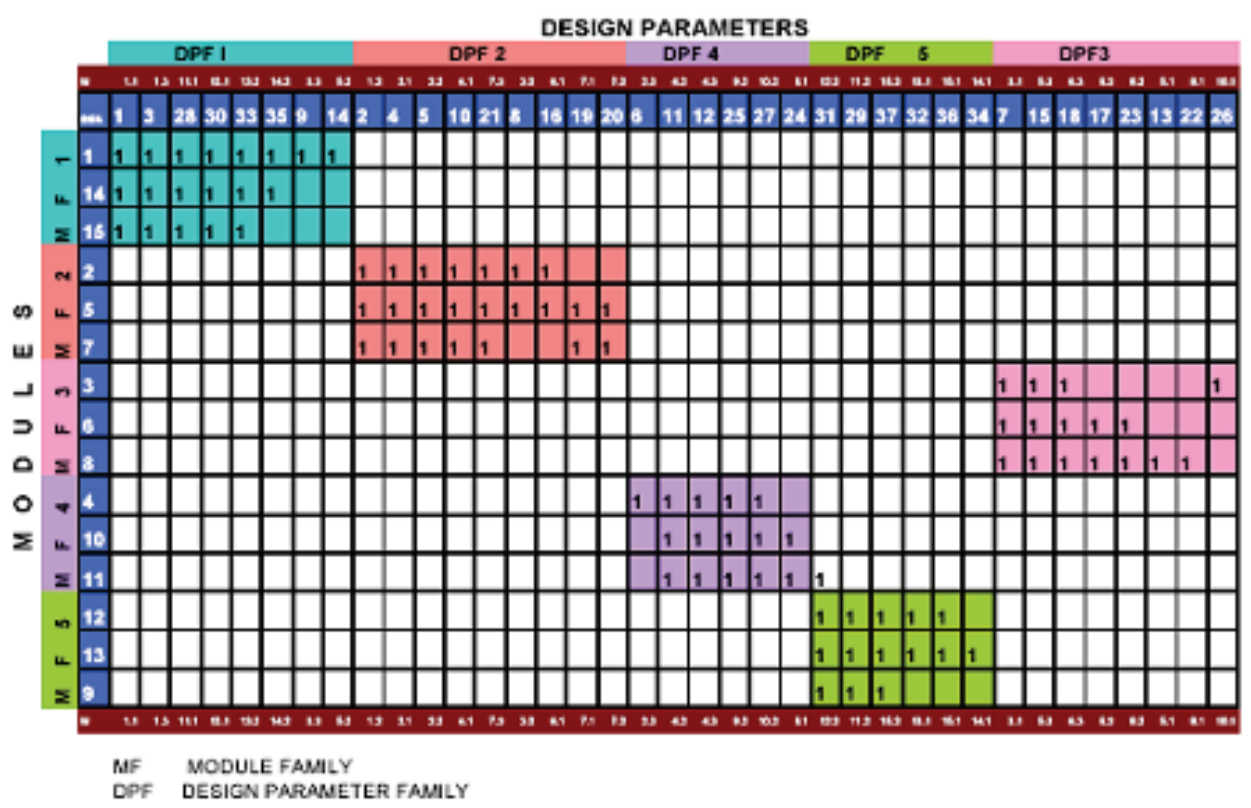

Figure 3: Clusters for logistics integrated product design

The final solution obtained by using this algorithm is independent of the order in which the rows and columns are presented. This methodology generates modules that are cohesive, bounded, or contain a self-contained group of activities. For effective implementation of integrated logistics design, each module solves one clearly-defined segment of the total system. The solutions are finite and applicable to new designs, as well as to existing designs.

\section{REFERENCES}

\section{Books}

[1] Ballou, R.H. 1987. Basic business logistics. $2^{\text {nd }}$ edition. Englewood Cliffs, New Jersey: Prentice Hall.

[2] Blanchard, B.S. 2000. Logistics engineering and management. New Delhi: PrenticeHall, Inc.

[3] Prasad, B. 1996. Concurrent engineering fundamentals in integrated product development, Vol. II. Upper Saddle River, NJ: PTR Prentice-Hall.

[4] Blanchard, B.S. and Fabrycky, W.J. 1998. Systems engineering and analysis. ( ${ }^{\text {rd }}$ edition. Upper Saddle River, NJ: Prentice Hall.

[5] Christopher, M. 1998. Logistics and supply chain management Delhi: Pearson Education, Inc.

\section{Articles}

[6] Kusiak, A. 2000. Data analysis: Models and algorithms. Proceedings of the SPIE Conference on Intelligent Systems and Advanced Manufacturing, P.E. Orban and G.K. Knopf (eds), SPIE, Vol. 4191, Boston, MA, November 2000, pp. 1-9. 
[7] Kusiak, A. and Huang, C. 1997. Design of modular digital circuits for testability, IEEE Transactions on Components, Packaging and Manufacturing Technology, Part C, Vol. 20, No.1.

[8] Gnanasekaran, J.S. and Shanmugasundaram, S. 2002. Optimization in designing for logistics support: A concurrent engineering approach. Proceedings of International Conference on E-manufacturing, India, pp. 359-365.

[9] Gnanasekaran, J.S. and Shanmugasundaram, S. 2003. Concurrent engineering approach for modeling to the logistics, Proceedings of International Conference on Mechanical Engineering, Dhaka, Bangladesh, ICME2003-AM-31.

[10] Gnanasekaran, J.S. and Shanmugasundaram, S. 2004. Pioneer-manufacturing achievements through concurrent engineering. International Mechanical Engineering Conference (IMEC-2004), Kuwait, December 5-8, 2004.

[11] Gnanasekaran, J.S. and Shanmugasundram, S. 2006. Manufacturing logistics Research implications. National Conference on Recent Advances in Product Design, Materials Technology and Manufacturing Systems (RAPMATS-06), Anna University, Chennai, January 6-7, 2006.

[12] Gnanasekaran, J.S. and Shanmugasundaram, S. 2007. Logistics integrated product design under concurrent engineering environment. International Conference on Manufacturing Engineering and Engineering Management (ICMEEM 2007) under World Congress on Engineering (WCE 2007), London, U.K., July 2-4, 2007.

[13] McCormick, W.T. Jr., Schweitzer, P.J. and White, T.W. 1972. Problem decomposition and data reorganization by a clustering technique. Operations Research 20 (5), pp. 993-1009.

[14] Kovaicheliyan, V. 1999. Concurrent engineering experience of Indian companies. A Cover Story, The Machinist, May-June, pp. 8-14.

[15] Zangwill, W.I. 1992. Concurrent engineering concepts and implementation. Engineering Management Review, Winter, pp. 40-52. 